\title{
Bare en journalistisk konstruktion? \\ En diskussion om journalistisk selvopfattelse
}

\section{AF CARSTEN JENSEN OG CHRISTIAN BREINHOLT}

Denne artikel beskæftiger sig med det helt fundamentale spørgsmål om, hvad journalistik i grunden er - og/eller burde være. ${ }^{1}$ Den mest udbredte selvopfattelse kan koges ned til denne sætning: Journalistik handler i al sin enkelthed om at indsamle nogle oplysninger og formidle dem til læseren/lytteren/seeren - og kernen i journalistik er at gøre folk klogere. Denne opfattelse af journalistik går igen i mange af fagområdets bøger, og den er bl.a grundigt behandlet - og forsvaret - i Lars Bjergs bog fra 2005 „Vær god - om etik, værdier og kvalitet i journalistik“. Samtidig har tankegangen bag denne selvopfattelse i mange år dannet grundlaget for journalistuddannelsen i Danmark. Denne artikel vil tillade sig at sætte spørgsmåltegn ved det rigtige og det hensigtsmæssige i en sådan opfattelse af faget. Definitionen er baseret på dels en transmissions-tankegang, hvor informationer flyttes fra $A$ til B, og dels på det formål, man ønsker at opnå via journalistikken, $f x$ at gøre borgerne klogere. Begge dele er problematiske ud fra en socialkonstruktivistisk opfattelse, som vi her vil argumentere for, idet en definition alene må baseres på de metoder, der anvendes i faget.

Der er mange grunde til at interessere sig for Lars Bjergs bog „Vær god“. Bogen præsenterer en teoretisk funderet definition på, hvad journalistik er, kan være - og bør være. Den handler således om det mest fundamentale inden for faget, - jf. dens un- 
dertitel. Den inddrager flere filosofiske retninger i en diskussion om rigtigheden af den mest udbredte selvopfattelse af, hvad der forstås ved journalistik. Forsvaret for denne opfattelse - og specielt afvisningen af socialkonstruktivismen - er imidlertid efter vores opfattelse forkert. Af disse grunde danner „Vær god“ udgangspunkt for denne artikel.

Artiklen begynder med en præsentation af journalistikopfattelsen i „Vær god“, herunder Lars Bjergs diskussion - og afvisning - af andre tilgange til faget end transmissions-tankegangen. Derefter følger en præsentation af socialkonstruktivismen - og vores kritik af Bjergs position. Begge afsnit er ret abstrakte og afkoblede fra dagligdagens mere konkrete debatter om journalistisk arbejde, da argumenterne overvejende er hentet fra sociologiske og filosofiske analyser. Herefter ser vi på, hvilke konsekvenser vores kritik har for den mere traditionelle opfattelse af både, hvad journalistik er (selve definitionen på journalistik), og hvad journalistik kan voere (journalistikkens mulighedsbetingelse). Vores grundlæggende pointe er, at man i højere grad end hidtil bør inddrage især modtageren i kommunikationsprocessen, når man søger at indkredse, hvad journalistik er. Dette kan ske uden at kaste vrag på den journalistiske integritet.

\section{Journalistik og objektivitet - et nyt eksempel på en traditionel position}

Lars Bjergs bog er egentligt en bog om fagetik. Dvs. at Bjerg i bogen behandler spørgsmålet om, hvordan journalister kan handle etisk korrekt. En sådan diskussion kræver først en afklaring af, hvad journalistikken er og kan være: Det vil jo ikke give megen mening at kræve, at journalister skal handle på en bestemt måde (den etisk korrekte), hvis dette ikke er muligt eller i det hele taget falder uden for det, man forstår som journalistik. Af samme grund bruger Bjerg en stor del af sin bog på netop at definere, hvad han mener journalistik er og kan være - for så senere at diskutere hvad journalistikken bør være, dvs. den etiske dimension. I dette essay ser vi bort fra dette sidste element og koncentrerer os i stedet om den første del.

Forskellen mellem hvad journalistikken er, og hvad den kan 
være, er beskeden - ikke mindst når vi som her vælger en abstrakt tilgang til emnet. Ikke desto mindre kan det være analytisk givtigt at forsøge at skelne mellem de to begreber. Således lægger Bjerg ud med at præsentere sin definition af, hvad journalistik er, nemlig en proces, der går ud på at

„finde, bearbejde og formidle sande og relevante informationer, så de er brugbare for en given målgruppe. At informationerne er brugbare, forudsætter, at journalisten er i stand til at skelne væsentligt fra uvæsentligt og skabe sammenhæng og forståelse og formidle effektivt. At formidle effektivt betyder at fortælle troværdigt, spændende og forståeligt“ (Bjerg, 2005: 39, vores kursivering).

To forhold er her af stor interesse. For det første er der et klart fokus på journalistens rolle som den aktive (som den, der skelner, skaber og formidler) - i modsætning til fx modtageren. For det andet bemærker man, at definitionen opstiller en del forudsætninger om journalistikkens mulighedsbetingelse. Det der især forudsættes er, at journalisten rent faktisk evner at „skelne væsentligt fra uvæsentligt og skabe sammenhæng og forståelse“. Derfor fordrer Bjergs definition, at modtagerne modtager information, uden at denne bliver forvansket. Eller sagt med andre ord: Bjerg forudsætter, at det er muligt for det første at indhente og for det andet at videreformidle information objektivt. Dette er, som vi skal se, to helt centrale præmisser for Bjerg og dermed også for dette kapitel.

For at underbygge denne forudsætning diskuterer Bjerg nogle centrale videnskabsteoretiske retninger. Fx bliver den såkaldte socialkonstruktivisme behandlet både ret grundigt og ret kritisk. I Bjergs fremstilling er det således ikke mindst socialkonstruktivismen og dens idéhistoriske forløbere, der står som eksponent for en grim relativisme, dvs. en negativ opfattelse af muligheden for objektiv erkendelse. Den grundlæggende pointe hos socialkonstruktivismen er, at virkeligheden er en sproglig konstruktion. Eller med Bjergs egne ord: 
„For dem alle [socialkonstruktivisterne] gælder det, at den konstruerede virkelighed ikke kan siges at være sand. Den er bare vedtaget og derefter forseglet med vor kulturs begrebsapparat. Men man kunne lige så godt have vedtaget noget andet.“ (Bjerg, 2005: 67).

Det er Bjergs opfattelse, at socialkonstruktivismen er et vildskud, idet den uvægerligt må medføre, at enhver forestilling om objektivitet $\mathrm{i}$ journalistikken må fraviges. Som vi skal se senere, er dette langt fra sikkert, men først skal vi i næste afsnit præsentere socialkonstruktivismen lidt mere grundigt og argumentere for, at Bjergs argument for afvisningen af socialkonstruktivismen ikke holder vand.

\section{Socialkonstruktivisme}

Pointen hos socialkonstruktivismen er som allerede nævnt, at virkeligheden er skabt via social interaktion mellem mennesker, hvilket som regel vil sige via sproget (også kaldet italesættelse). Blandt socialkonstruktivisterne findes der en række forskellige skoler, der især adskiller sig ved, hvordan man bør forstå begreberne „virkeligheden“ og „skabt“ - og som vi skal se har dette potentielt stor betydning (for oversigter se Wenneberg, 2000; Collin, 2003).

For det første er der uenighed om, hvilken „virkelighed “ det er, der italesættes - er det den sociale eller den fysiske virkelighed? Den sidste holdning er klart den mest radikale, idet det med denne påstås, at det er selve den fysiske verden - træer, huse osv. - der bliver skabt via sociale processer. Der findes intet foruden individet og så Gud, alt andet er så at sige ren fantasi, som den gamle Berkeley (2000) sagde. Moderne forfattere inden for skolen er ofte mindre rabiate og har en tendens til at glide bort fra denne position. Den alternative skole, at det alene er den sociale virkelighed, der er skabt, har en væsentlig større tilhængerskare. Denne skole står sammen om en påstand om, at sociale fænomener, $\mathrm{fx}$ bryllupper, penge og krige, er skabt som følge af menneskers sociale interaktion med hinanden.

For det andet er der uenighed om, hvad der bør forstås med or- 
det ,skabt“. Dette kan nemlig både forstås ontologisk og epistemologisk. Ontologiens fokus er virkelighedens natur med grundspørgsmålet: Hvad eksisterer? De ontologiske socialkonstruktivisters svar er, at virkeligheden på den ene side har en eksistens, der er uafhængig af vores konstruktioner, men på den anden side kun kan erfares som en konstruktion (,tingen som den fremtræder for os") og aldrig direkte, som den egentlig er („tingen i sig selv“). Epistemologiens fokus er erkendelsens natur med grundspørgsmålet: Hvordan kan vi vide det? De epistemologiske socialkonstruktivisters svar er, at vi konstruerer vores virkelighed på baggrund af intentionelle handlinger, og at erkendelserne organiseres i nogle helheder efter nogle bestemte regler. Nye erkendelser konstrueres gennem indpasning i disse helheder, og denne konstruerede virkelighed testes løbende gennem vore handlinger og de konsekvenser, vi oplever som følge af disse handlinger. ${ }^{2}$

Alt i alt får man således fire forskellige socialkonstruktivistiske skoler, der er opsummeret i figur 1.

\section{Figur 1}

Fire socialkonstruktivistiske skoler (inspireret af Collin, 2003: 24).

\begin{tabular}{|l|l|l|}
\hline \multicolumn{2}{|l}{ Sociale fænomener } & \multicolumn{1}{l|}{ Fysiske fænomener } \\
\hline Epistemologi & $\begin{array}{l}\text { (A) Erkendelsen af at } \\
\text { sociale fænomener er } \\
\text { betinget af } \\
\text { social interaktion }\end{array}$ & $\begin{array}{l}\text { (B) Erkendelsen af at } \\
\text { fysiske fænomener er } \\
\text { betinget af } \\
\text { social interaktion }\end{array}$ \\
\hline Ontologi & $\begin{array}{l}\text { (C) Sociale fænomener er } \\
\text { skabt via social interaktion }\end{array}$ & $\begin{array}{l}\text { (D) Fysiske fænomener er } \\
\text { skabt via social interaktion }\end{array}$ \\
\hline
\end{tabular}

Ovenstående korte gennemgang tjener det formål at anskueliggøre, hvordan Bjerg når frem til, at socialkonstruktivismen bør forkastes, samt hvorfor denne holdning efter vores opfattelse er en misforståelse. Når Bjerg således skal argumentere for, hvorfor han ikke mener socialkonstruktivismen holder, henviser han langt overvejende til eksempler fra de mest radikale udgaver (celle B og D i figur 1) - også selvom han anerkender eksistensen 
af de mere moderate og oven i købet pointerer, at de udgør et flertal. Bjergs pointe er således, at en forestilling om, at den fysiske virkelighed er konstueret via social interaktion grundlæggende, er uholdbar, fordi dette vil medføre en uacceptabel grad af relativisme, hvor „hvis jeg lissom føler, at det er tirsdag i dag, så er det altså tirsdag i dag. For mig“ (Bjerg, 2005: 68; se desuden pp. 62-80, 84-85, 108). Der er to relaterede problemer med dette argument.

For det første bruger Bjerg som nævnt eksempler fra de mest radikale udgaver til at forkaste alle de socialkonstruktivistiske skoler, altså også de mere moderate (celle A og C i figur 1). Dette er imidlertid ikke en rimelig fremgangsmåde, fordi der ikke findes nogen nødvendig sammenhæng mellem de moderate og de radikale skoler. Man kan med andre ord sagtens være en moderat socialkonstruktivist, der mener, at den sociale virkelighed er skabt via sociale interaktioner, uden at man dermed tilslutter sig den radikale socialkonstruktivisme, der mener, at også den fysiske virkelighed er konstrueret. Både John Searle (1995) og Anthony Giddens (1984) har gjort et stort arbejde for at påvise denne pointe.

For det andet er det et problem, at Bjerg i sin fremstilling tilskriver socialkonstruktivismen en meget høj grad af relativisme, hvor der med relativisme menes, at det enkelte individ levnes en stor margin til at påvirke både sociale og fysiske fænomener. Her bør det imidlertid påpeges, at Bjerg overser det væsentlige forhold, at socialkonstruktivisterne stort set alle som én netop understreger, at det er social interaktion, der skaber fænomenerne. Hermed fremhæves det, at der kræves en form for social konsensus blandt en større gruppe af mennesker, før et fænomen bliver konstitueret. For det enkelte menneske er der derimod ikke megen valgfrihed: Hvis man fx bryder den sociale konsensus om, at et bryllup er et bryllup og ikke en polterabend, begår man normbrud og vil som regel blive sanktioneret tilsvarende. Det er iøvrigt af samme årsag, at man inden for politologien ofte taler om interaktionsregler, når man behandler betydningen af den sociale interaktion for det enkelte individ (fx Östrom, 1986).

Det er altså vores pointe, at Bjerg ikke synes at have afvist socialkonstruktivismen særlig godt. Desuden viser den moderate socialkonstruktivismes store popularitet inden for medie- og 
samfundsvidenskaberne, at retningen har noget for sig. Der er ikke her plads til at forsøge mere positivt at bevise socialkonstruktivismens rigtighed udover at fremhæve, at den analytisk har vist sig meget frugtbar utallige gange - og så naturligvis endnu engang at understrege, at det ikke er lykkedes retningens modstandere (her personificeret ved Bjerg) at påvise dens manglende gyldighed.

Selvom disse pointer kan synes abstrakte, har de stor betydning for den måde, vi kan begribe journalistikken og den mulighedsbetingelse på. Hvis man som Bjerg fuldstændigt fravælger socialkonstruktivismen ved forståelsen af journalistik, kan man tilsyneladende kun gå én vej - den traditionelle - men hvis man tilslutter sig den moderate socialkonstruktivisme, åbner der sig et bredere perspektiv.

\section{Konsekvenser for journalistikkens mulighedsbetingelse}

Journalistikkens mulighedsbetingelse betegner som nævnt det, som journalistikken og dens udøvere kan gøre. Når Bjerg i sin bog gør så meget ud af at afvise socialkonstruktivismen skyldes det, at tilgangen medfører, at man må forkaste enhver forestilling om, at objektivitet er mulig. Man vil således ikke efter Bjergs opfattelse kunne skelne mellem god og dårlig journalistik. Bjergs pointe er toleddet. For det første er han stærkt bekymret over relativismen, hvor enkeltindivider så at sige tiltager sig retten til at bestemme, hvad virkeligheden er. Men som det blev påvist ovenfor, er dette næppe en reel risiko, fordi den moderate socialkonstruktivisme fremhæver betydningen af sociale interaktionsregler.

For det andet er det Bjergs opfattelse, at det faktisk er muligt for journalister, ,at skelne væsentligt fra uvæsentligt og skabe sammenhæng og forståelse og formidle effektivt“ (Bjerg, 2005: 39). Heri ligger ikke en påstand om, at journalister - eller nogen som helst andre for den sags skyld - fuldstændigt kan afdække alle sandheder; men der ligger en påstand om, at enhver (veluddannet/god) journalist kan indhente og videreformidle informationer, som er meget tæt på at være objektivt korrekte - og som andre journalister og personer vil kunne genskabe, hvis de måtte 
ønske det. Det er altså muligt ved hårdt arbejde for hver enkelt journalist at nå frem til konklusioner, som alle andre enkeltindivider vil være enige i og selv kunne nå frem til, hvis disse også forsøgte at sætte sig ind i sagerne.

Det er imidlertid en temmelig problematisk antagelse, der her bliver gjort, ikke mindst hvis man vælger et socialkonstruktivistisk udgangspunkt. Den grundlæggende (og moderate) socialkonstruktivistiske pointe er således, at det ikke er rimeligt at forvente, at forskellige enkeltindivider vil kunne genskabe hinandens konklusioner, uanset hvor megen tid de fik stillet til rådighed. Hvorvidt dette er muligt er nemlig afhængigt af, hvilken social kontekst, disse individer indgår i.

Blandt andre Giddens (1984) har behandlet dette spørgsmål indgående. Giddens' første pointe, der deles af mange andre socialkonstruktivister (fx Michel Foucault og Niklas Luhman), er kort fortalt, at vores opfattelse af tingenes tilstand er stærkt påvirket af de sociale omgivelser, hvori vi befinder os. Pointen er yderligere den, at der ikke findes nogen „kontekstneutral“ position, hvor man kan hæve sig over de sociale omgivelsers påvirkning. Man kan ikke pludseligt beslutte sig for at lade sig selv afsocialisere - samfundsiagttagere, ${ }^{3}$ dvs. både forskere og journalister, er altid nødsaget til at tolke virkeligheden fra deres eget ståsted.

Den anden pointe er, at den sociale virkelighed har en helt anden karakter end den fysiske, og at dette har stor betydning for, hvordan samfundsiagttagere kan virke. Hvor den fysiske virkelighed så at sige ikke kan svare tilbage og i det hele taget på mange måder er helt upåvirkelig af menneskelig aktivitet, da forholder det sig modsat med den sociale virkelighed. Den sociale virkelighed er netop ensbetydende med menneskelig aktivitet - og en stor del af denne menneskelige aktivitet består i at tolke hverdagen, idet det dermed bliver muligt at skabe sammenhæng og mening i tilværelsen.

Disse hverdagstolkninger er noget, alle mennesker foretager sig næsten hele tiden, men oven i dette kommer så samfundsiagttagerne og foretager deres tolkning af hverdagstolkningen. Og for at gøre forvirringen komplet: Når journalisterne og forskerne har foretaget deres tolkning, indgår denne tolkning deref- 
ter ofte i den sociale virkelighed. Der findes således mange eksempler på, at en ny undersøgelse (altså en tolkning af den sociale virkelighed) omformer den selv samme virkelighed, fordi offentligheden med ét slag får en ny dagsorden eller et nyt perspektiv.

Dette cirkelagtige forløb går i Giddens' arbejde under betegnelsen den dobbelte hermeneutik. Den grundlæggende pointe er, at samfundsiagttageren påvirker det samfund han iagttager normalt ganske lidt, men nogle gange ganske meget - og at samfundet ikke er nogen neutral genstand. Samfundet påvirker også iagttageren. Dels ved at ændre karakter, når det fortolkes, og dels ved i det hele taget at påvirke iagttageren gennem dennes socialisering. Det er klart, at en sådan konklusion har stor betydning for journalistikkens mulighedsbetingelse, fordi selve idéen om, at hin enkelte journalist skal kunne researche sig til historier, der er tilnærmelsesvist objektive, så må modificeres.

\section{Journalistik som socialkonstruktivisme}

Som nævnt er Bjergs position udtryk for, hvad man kunne kalde den traditionelle opfattelse inden for dansk journalistik - som denne fx kommer til udtryk i Danmarks Journalisthøjskoles studieordning og mange andre steder. Opfattelsen synes at være meget lidt påvirket af digitaliseringsudviklingen på medieområdet, fx fremkomsten af weblogs, de såkaldte web 2.0 værktøjer, „social software“ osv., som på en hel anden måde end tidligere muliggør en inddragelse af brugerne i medieprodukter. Og samtidig synes opfattelsen meget lidt påvirket af de faglige tendenser på kommunikationsområdet, fx skiftet fra kundepåvirkningstankegangen til partnerskabs-tankegangen. Den passive modtager er i løbet af det seneste tiår begge steder erstattet af en opfattelse af noget, der kan sammenfattes i begrebet „modtageren som betydnings- og medproducent“. Hele denne udvikling også af journalistikkens mulighedsbetingelser - kan bedst analyseres ved hjælp af en socialkonstruktivistisk tilgang.

For at belyse det begrænsede - og begrænsende - ved Bjergs definition, kan vi sætte hans opfattelse af journalistik ind i en kommunikationssammenhæng. Med et udtryk fra James W. Ca- 
reys (1988/1992) socialkonstruktivistiske teori kan vi benævne Bjergs opfattelse som meget transmissionspræget, altså præget af en forståelse, hvor journalistik handler om at få sendt et bestemt budskab fra en afsender til en modtager. Budskabet forventes ud fra denne forståelse at blive rekonstrueret (og netop ikke konstrueret) i modtagerens hoved. Med en sådan opfattelse af kommunikationsprocessen handler journalistik om at påvirke publikum (fx gøre dem klogere) via sande og relevante informationer, som overføres direkte til dem. Fokus på den gode journalists uddannelse og virke vil derfor være på dokumentation og formidling. Derfor bliver de centrale analysespørgsmål: Er det sandt? Bliver det formidlet effektivt?

Hvis man imidlertid betragter journalistik ud fra en anden kommunikationsopfattelse - den socialkonstruktivistiske - bliver der et helt andet, og meget bredere, fokus. Dette kunne med Careys ord benævnes som en opfattelse, hvor man ser kommunikationsprocessen som et ritual. Hvor transmissionsopfattelsen har transport som metafor, har ritualopfattelsen en ceremoni, hvor en gruppe mennesker er sammen for at skabe og styrke en fælles forståelse af verden. Hvor transmissions-synsvinkelen taler om en afsender og en modtager, vil ritual-synsvinkelen betone, at der er tale om deltagere i en fælles proces, en proces hvor verden bliver konstrueret og vedligeholdt som en meningsfuld kulturel verden. Ritual-synsvinkelen vil således ikke se journalistik som information i traditionel forstand, men som drama, der er bundet til tid og sted, men som inviterer til deltagelse, til fortolkning og følelser. Det centrale analysespørgsmål vil her gå i retning af, hvorvidt den givne kommunikationsproces får skabt en meningsfuld verdensopfattelse blandt deltagerne. Alle disse forskelle kan anskueliggøres i figur 2.

Ovenstående er bare et enkelt eksempel på en anden og mere socialkonstruktivistisk tilgang til en fastlæggelse af faget, som her er brugt til vise, at Bjergs afvisende holdning til socialkonstruktivisme indsnævrer forståelsen af journalistikkens mulighedsbetingelser.

Med en forståelse for journalistik - og i bredere forstand kommunikation - som blot og bar informationsoverførsel udelukker man en masse relevante emneområder. Bjergs forståelse er end- 


\section{Figur 2}

To syn på kommunikationsprocessen (inspireret af Carey, 1988/1992: 18).

\begin{tabular}{|c|c|c|c|}
\hline & & $\begin{array}{l}\text { Transmissions- } \\
\text { synsvinklen }\end{array}$ & $\begin{array}{l}\text { Ritual- } \\
\text { synsvinklen }\end{array}$ \\
\hline \multirow{5}{*}{$\begin{array}{l}\text { Kommu- } \\
\text { nikation } \\
\text { generelt }\end{array}$} & Metafor & Transport & Ceremoni \\
\hline & Roller & Afsender og & Deltagere \\
\hline & Funktion & $\begin{array}{l}\text { Indflydelse } \\
\text { over afstand }\end{array}$ & $\begin{array}{l}\text { Fællesskab } \\
\text { over tid }\end{array}$ \\
\hline & $\begin{array}{l}\text { Funktions- } \\
\text { processer }\end{array}$ & Sendt og modtaget & $\begin{array}{l}\text { Skabt og } \\
\text { genskabt }\end{array}$ \\
\hline & Succeskriterier & Korrekt overførsel & Fælles opfattelse \\
\hline \multirow[t]{3}{*}{ Journalistik } & Forståelse & $\begin{array}{l}\text { Informations- } \\
\text { formidling }\end{array}$ & $\begin{array}{l}\text { Social } \\
\text { konstruktion }\end{array}$ \\
\hline & $\begin{array}{l}\text { Funktion (bevidst } \\
\text { eller ubevidst) }\end{array}$ & $\begin{array}{l}\text { Afspejling af } \\
\text { verden }\end{array}$ & $\begin{array}{l}\text { Skabelse af } \\
\text { verden }\end{array}$ \\
\hline & $\begin{array}{l}\text { Analytisk } \\
\text { fokus }\end{array}$ & $\begin{array}{l}\text { Empirisk } \\
\text { dokumentation, } \\
\text { rationalitet, indhold }\end{array}$ & $\begin{array}{l}\text { Ideologisk } \\
\text { forståelse, } \\
\text { følelser, form, } \\
\text { social kontekst }\end{array}$ \\
\hline
\end{tabular}

da så snæver, at han stort set ikke behandler modtagernes opfattelse af budskabet i en bog, der handler om kvalitet i journalistik. Med en definition knyttet til „at gøre modtageren klogere“ kunne man have forventet, at han ville reflektere over, i hvilket omfang og på hvilken måde modtageren så også rent faktisk blev klogere.

Som eksempel på de emneområder, som Bjerg og den traditionelle journalistikopfattelse ikke får behandlet, kan vi se på, hvilke spørgsmål man ud fra de to opfattelser ville stille til en undersøgelse af dagbladsjournalistik. Ud fra et transmissionssyn ville man se avisen som et middel til at få udbredt nogle nyheder, og blandt de oplagte spørgsmål kunne være: Hvad bliver der oplyst om, hvilken dokumentation er der, hvilke formidlingsformer bruges osv. Ud fra et ritual-syn vil de oplagte spørgsmål gå på emner som: Hvilken type verdensopfattelse bliver der skabt og 
opretholdt, hvilke roller i dramaet er på spil for læseren osv. Hver eneste journalistiske produkt om fx velfærdsspørgsmålet i efteråret 2006 kan således både opfattes som endnu et led i den fortsatte klassekamp, et teknisk spørgsmål om nationaløkonomisk overophedning eller et konkret spørgsmål om egne pasningsmuligheder. Om det bliver den ene eller den anden fortolkning, der får mest vægt, afhænger ikke mindst af modtagerens ressourcer og verdensopfattelse. Som enhver anden kommunikation er der ikke alene tale om en transmission, ${ }^{4}$ men om en særlig "presentation of reality that gives life an overall form, order, and tone“ (Carey, 1988/1992: 21).

\section{Konsekvenser for definitionen af journalistik}

Med omtalen af Careys teori har vi efterhånden bevæget os helt tæt ind på spørgsmålet om, hvordan man bør definere journalistik. For hvordan kan man egentligt forstå journalistik, hvis de ovenstående argumenter holder? Det er oplagt, at Bjerg har en vigtig pointe $i$, at manglende objektivitet $i$ bred forstand kan være et problem. Det kan således være svært at acceptere, at der er frit spil til at skrive hvad som helst og samtidigt kalde det journalistik. Men hvordan er det muligt at kombinere et socialkonstruktivistisk udgangspunkt, hvor forskellige sociale aktører (journalister, modtagere, kilder) anses som værende stærkt påvirkede af - og påvirkende på - deres omgivelser, med et ønske om at sikre den journalistiske integritet og særstatus? Svaret ligger, efter vores opfattelse, i at gå fra den traditionelle formålsbaserede definition af journalistik til en definition, som er baseret på bestemte metoder.

Den formålsbaserede definition er kendetegnet ved, at formålet for journalistikken anskues som det definerende træk ved selv samme journalistik, altså det, der adskiller journalistik fra $\mathrm{fx}$ sociologi eller politologi. Fx er journalistikken for Bjerg kendetegnet ved, at man gør folk klogere (Bjerg, 2005: 39), men også andre forfattere læner sig op af denne type definition. Således fremhæver Flemming Svith følgende passage fra Medieudvalget af 1996’s betænkning, når han skal pege på det unikke ved journalistik: 
„Journalistik har som som mål at etablere meninger og viden om de samfundsmæssige levevilkår, at bidrage til at danne grundlag for deltagelse i beslutningsprocesser eller danne grundlag for kritik af myndigheders, virksomheders og gruppers adfærd.“ (Svith, 2006: 171)

Fra en socialkonstruktivistisk synsvinkel bliver spørgsmålet imidlertid: Hvilke meninger? Hvilken viden? Man kan være hård og sige, at der er sagt meget lidt med en sådan definition - og i hvert fald kan man sige, at den ikke indeholder en garanti for indholdet af journalistikken. Eller sagt på en anden måde: Meninger og til dels også viden etableres kontinuerligt i samfundet som følge af menneskers sociale interaktion, men dermed er det også sagt, at dette næppe kan være det unikke, definerende træk ved journalistik. Hvordan skulle man på denne baggrund adskille journalistik fra diverse videnskabelige discipliner? Hvorfor skal journalistik fx gøre folk klogere - og hvem har bestemt det? Og kan dele af skønlitteraturen iøvrigt ikke også have til formål at gøre folk klogere? Spørgsmålene er både mange og store.

Alternativet er at fokusere på de journalistiske metoder. På denne måde viger man uden om den fare for subjektivitet og tilfældighed, der helt tydeligt er forbundet med de formålsbaserede definitioner. Metoder - og herunder naturligvis journalistiske metoder - er kendetegnet ved deres afkobling fra den genstand, der bliver undersøgt, og vedkommende, der undersøger den. Det er netop denne afkobling, som gør, at et fokus på metoder er så attraktivt.

Fra et socialkonstruktivistisk perspektiv er det således særlig attraktivt, at metoder kan dokumenteres og granskes, uden at der deri ligger en påstand om, at forskellige personer nødvendigvis ville kunne nå frem til de samme konklusioner uafhængigt af hinanden. Men samtidig indskrænker man klart mulighederne for at kalde hvad som helst journalistik, netop fordi visse metodiske forskrifter skal overholdes for at falde ind under definitionen. ${ }^{5}$ Man kan sammenligne det med fodbold: Man må ikke bruge armene eller være off-side, men derudover gælder det bare om at få bolden i nettet.

For så vidt man anerkender det givtige i at anlægge et meto- 
defokus, da bliver det næste spørgsmål, hvordan det så bliver muligt at adskille journalistikken fra alle mulige andre samfundsvidenskablige discipliner. Svaret er toleddet. Det er oplagt, at journalistikken normalt er underlagt en række strukturelle betingelser såsom korte deadlines osv., der ofte betinger en anden metodebrug end i de regelrette videnskaber. Men forskellen er ikke definitorisk, ligesom metodebrugen sagtens kan være rimeligt systematiseret uden at nå samme niveau som samfundsvidenskaben (Boolsen, 2006: 82; Svith, 2006: 186-189). Til gengæld er det vores opfattelse, at det særlige ved journalistikken kan indkredses, hvis man kombinerer metodebrugen (bestemt af de korte deadlines) med forskellige modtagergrupper.

Denne pointe ligger i forlængelse af socialkonstruktivismen (og særligt Carey), hvor der som ovenfor beskrevet netop er et fokus på modtagerens betydning. Man kan forestille sig mange inddelinger af modtagertyper, men en simpel dikotomi kunne være mellem et massepublikum og eksperter, hvor eksperter forstås bredt som alle der til dagligt arbejder med et bestemt område. Det er klart, at en sådan opdeling har umiddelbar relevans, når man fx skal søge at skelne mellem journalistik og en lang række videnskablige discipliner, der ofte vil behandle de samme emner, men med vidt forskellige målgrupper. Samlet kan man altså forestille sig en inddeling som vist i figur 3 .

I figur 3 er forskellige typer samfundsiagttagelse for det første indplaceret efter metodevilkår, nærmere bestemt deadlines, fordi dette forventes at fortælle noget - men naturligvis ikke alt om, hvor systematisk en metodebrug, der kan finde sted. Tidsfaktoren (deadlines) får ekstra betydning i disse år, hvor selve nyhedsrummet - det nyhedshul, der skal fyldes hver dag, uanset hvad der er sket - udvides. (Flere produkter, flere platforme, tvnyheder hele døgnet m.m.). For det andet er typerne af samfundsiagttagelse indplaceret efter de formidlingsvilkår, der er gældende. Det er klart, at figur 3 ikke indfanger alle de mange typer af journalistik, der findes (jf. Svith, 2006), ligesom den konkrete indplacering kan diskuteres. Imidlertid er det muligt på baggrund af figur 3 og diskussionen, som ledte frem til den, at formulere en mere præcis definition på, hvad journalistik er: samfundsiagttagelse, der - baseret på en systematiseret og alment 


\section{Figur 3}

Forskellige typer samfundsiagttagelse defineret ved metodevilkår (deadlines) og formidlingsvilkår (modtagertype).

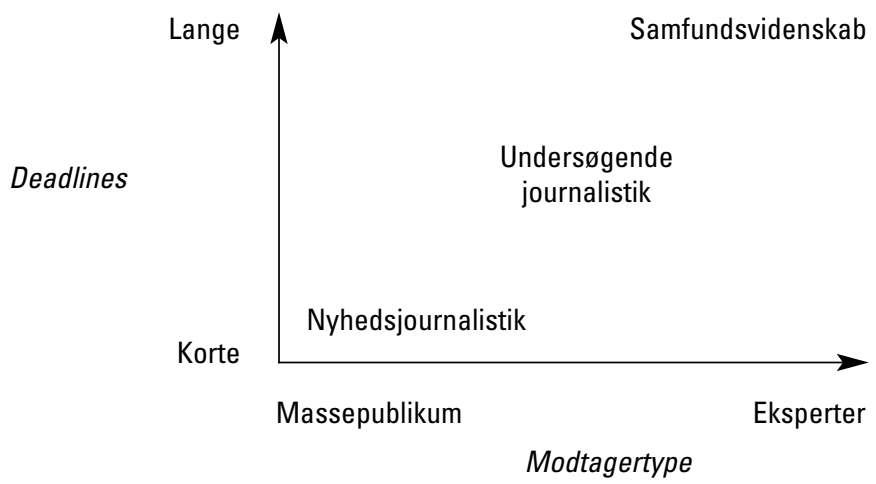

anerkendt metodeanvendelse og med relativt korte deadlines indgår i konstruktionen af verdenbillederne hos et massepublikum.

\section{Konklusion}

Allerede for mange år siden blev konstruktivistiske opfattelser præsenteret i dansk medielitteratur, og som Bjerg selv nævner, har socialkonstruktivismen „mange tilhængere på f.eks. medieog kommunikationsuddannelserne" (Bjerg, 2005: 67). Dette forhold synes dog ikke at påvirke hans tilgang - faktisk er hans bog mere transmissionspræget og anti-socialkonstruktivistisk end tidligere bøger (fra samme institution og forlag), der behandlede samme emner med henblik på spørgsmålet om journalistisk etik (Kruuse, 1991). En sådan reaktion på en ny forståelse og tilgang blev allerede i 1999 konstateret af den danske medieforsker Stig Hjarvard, idet han skrev:

„Når forskere med interesse for mediernes udtryksformer har fremhævet mere konstruktivistiske positioner, skal det bl.a. ses som en nødvendig retorisk position i opgøret med mere naive opfattelser af kommunikation som blot og bar informationsoverførsel. Reaktionen er dog ikke udeblevet. 
Ikke mindst journalister, der er blevet konfronteret med udsagn om, at deres nyhedsformidling blot var en social konstruktion, har reageret skarpt; ofte med den konsekvens, at de har argumenteret for et transmissionsideal.“ (Stig Hjarvard, 1999: 26)

Denne kritik til trods er der gode grunde til, at den traditionelle opfattelse af, hvad journalistik er og kan være, har nydt stor popularitet. Grunden er - som allerede antydet - at ingen, heller ikke denne artikels forfattere, ønsker at åbne døren for en relativisme, hvor hvad som helst kan kaldes journalistik. Imidlertid har vi i det ovenstående søgt at vise, at der ikke nødvendigvis behøver at være en sammenhæng mellem denne form for relativisme på den ene side og socialkonstruktivismen på den anden. Netop fordi socialkonstruktivismen betragter sociale fænomener som konstruerede af interaktionsregler, er den stærke form for relativisme, som Bjerg og andre frygter, næppe et realistisk scenario. Ved at definere journalistik som ovenfor burde det således være muligt både at anerkende, at den sociale virkelighed i én eller anden udstrækning er skabt via social interaktion, uden samtidigt at miste muligheden for at kalde noget for "god“ og noget andet for „dårlig“ journalistik.

På samme tid viste vi også, hvordan den traditionelle opfattelse af journalistik og dens mulighedsbetingelse virker begrænsende på de analyser, man kan foretage af journalistik. Med en socialkonstruktivistisk tilgang får man derimod et langt bredere perspektiv ved fx både at beskæftige sig med det transmissionsprægede og det rituelt prægede syn på kommunikationen. Den helt centrale pointe er således efter vores opfattelse, at man på én og samme tid kan tage den reelle bekymring for journalistikkens integritet alvorligt og sikre sig langt rigere analytiske muligheder. 


\section{NOTER}

1. Forfatterne ønsker at takke en række ansatte ved Danmarks Journalisthøjskole for kommentarer til et tidligere udkast, heriblandt Martin Vestergaard, Heidi Søndergaard Mathiesen og Kristian Strøbeck.

2. Betydningen af denne forskel mellem begreberne „virkelighed“ og „skabt“ er størst, når man ser på den fysiske virkelighed (se fx Collin, 1993; Nelson, 1994).

3. Samfundsiagttagelse skal her forståes i en aktiv betydning, idet såvel videnskabsmanden som journalisten forventes aktivt at afdække en virkelighed, der ofte ikke er, som den umiddelbart tager sig ud.

4. Læg mærke til, at Carey for så vidt også har et transmissionssynspunkt, selvom vi her fremhæver hans ritual-synspunkt. Carey betoner, at kommunikation både handler om tranmission og ritual: „Neither of these counterposted views of communication necessarrily denies what the other affirms. A ritual view does not exclude the processes of information transmission or attitude change. It merely contends that one cannot understand these processes aright except insofar as they are cast within an essentially ritualistic view of communication and social order" (Carey, 1988/1992: 21).

5. Det kan virke overraskende for nogle at koble socialkonstruktivismen med et så entydigt metodefokus, idet socialkonstruktivismen i hvert fald inden for sociologien ofte bliver kritiseret for at lide under et for løst metodebrug. Imidlertid har Simon Calmar Andersen påvist, at socialkonstruktivisme og stringent metodebrug så langt fra er hinandens modsætninger (Andersen, 2005).

\section{REFEREN CER}

Andersen, Simon Calmar (2005). „Smid ikke metoderne ud med badevandet. Epistemologisk konstruktivisme og dens metodiske konsekvenser“, Dansk Sociologi, 16. årgang, nr. 3, pp. 45-6o.

Berkeley, George (2000). Principperne for den menneskelige erkendelse, Frederiksberg: Det Lille Forlag.

Bjerg, Lars (2005). Voer god. Om etik, voerdier og kvalitet $i$ journalistik, Århus: Forlaget Ajour.

Boolsen, Merete Watt (2006). „Journalistisk kvalitetssikring - hvordan bliver analysen sand?“, pp. 79-103 i Flemming Svith (red.), At opdage 
verden. Research - Fra akademikere til journalister, Århus: Forlaget Ajour.

Carey, James W (1988/1992). Communication as Culture, New York: Routledge.

Collin, Finn (1993). „Social Constructivism Without a Paradox“, Danish Yearbook of Philosophy, 28. årgang, pp. 24-46.

Collin, Finn (2003). Konstruktivisme, Frederiksberg: Roskilde Universitetsforlag.

Giddens, Anthony (1984). The Constitution of Society, Berkeley \& Los Angeles: University of California Press.

Hjarvard, Stig (1999). TV-nyheder $i$ konkurrence, København: Forlaget Samfundslitteratur.

Kruuse, Helle Nissen (1991). Etik i journalistik, Århus: Forlaget Ajour.

Nelson, Alan (1994). „How Could Scientific Facts be Socially Constructed?“, Studies in History and Philosophy of Science, 25. årgang, nr. 4, pp. 535-547.

Searle, John (1995). The Construction of Social Reality, London: Penguin Books.

Svith, Flemming (2006). „Journalistens konklusioner“, pp. 168-194 i Flemming Svith (red.), At opdage verden. Research - Fra akademikere til journalister, Århus: Forlaget Ajour.

Wenneberg, Søren (2000). Socialkonstruktivisme - positioner, problemer og perspektiver, København: Samfundslitteratur.

Östrom, Elinor (1986). „An Agenda for the Study of Institutions“, Public Choice, 48. årgang, nr. 1, pp. 3-25. 